\title{
Ruthenium(II) carbonyl complexes containing thiourea ligand: Enhancing the biological assets through biomolecules interaction and enzyme mimetic activities
}

\author{
Paranthaman Vijayan ${ }^{1} \cdot$ Subbarayan Vijayapritha ${ }^{1}$. Chidambaram Ruba ${ }^{1} \cdot$ Periasamy Viswanathamurthi ${ }^{1}$. \\ Wolfgang Linert ${ }^{2}$ (1)
}

Received: 25 June 2018 / Accepted: 8 January 2019 / Published online: 20 May 2019

(C) The Author(s) 2019

\begin{abstract}
The ligand $\mathrm{H}_{2} \mathrm{~L}$ ( $N$-( $N, N$-diethylaminothiocarbonyl)benzimidoylchloride-2-aminoacetophenone- $N$-methylthiosemicarbazone) reacts with ruthenium(II) building blocks $\left[\mathrm{RuHCl}(\mathrm{CO})\left(\mathrm{EPh}_{3}\right)_{3}\right]\left(\mathrm{E}=\mathrm{P}\right.$ or As) to form new complexes $\left[\mathrm{Ru}(1,1-\mathrm{DT})(\mathrm{Cl})_{2}\right)(\mathrm{CO})-$ $\left.\left(\mathrm{EPh}_{3}\right)_{2}\right]\left(\mathrm{E}=\mathrm{P}\right.$ or As; $1,1-\mathrm{DT}=1$,1-diethylthiourea). The ligand $\mathrm{H}_{2} \mathrm{~L}$ in these reactions undergoes $\mathrm{C}=\mathrm{N}$ bond break and coordinates through sulfur atom of $\mathrm{C}=\mathrm{S}$ group. Analytical and spectral (IR, UV-Vis, NMR, ESI-MS) methods were used to characterize the compounds. A distorted octahedral geometry for complexes has been furnished by X-ray crystallography, which confirmed the coordination mode of the ligand with metal precursor. The binding affinity and mode of binding of the complex towards some important biomolecules such as calf thymus DNA and bovine serum albumin protein were determined using absorption and emission spectra and found intercalative binding with calf thymus DNA and static interaction with bovine serum albumin. The in vitro cytotoxic activity of complex was assessed using human cervical cancer (HeLa), human hepatocellular carcinoma (HepG2), and normal Vero cells. Furthermore, the complex was found to possess significant enzyme mimic catalytic activity in oxidation and hydrolysis reactions.
\end{abstract}

\section{Graphical abstract}

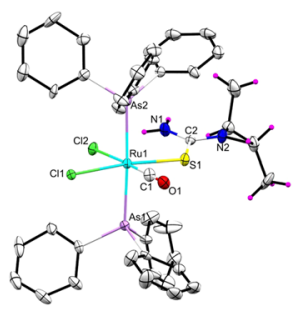

Keywords Thiourea $\cdot$ Ruthenium(II) complex $\cdot$ DNA/BSA binding $\cdot$ Enzyme kinetics

\section{Introduction}

Periasamy Viswanathamurthi

viswanathamurthi@gmail.com

Wolfgang Linert

wlinert@mail.zserv.tuwien.ac.at

1 Department of Chemistry, Periyar University, Salem, India

2 Institute of Applied Synthetic Chemistry, Vienna University of Technology, Vienna, Austria
In recent years, attention has been given for metallic drug-DNA interaction in inorganic pharmaceutical research. Due to the tunable coordination properties of the inorganic drugs, the interaction of transition metal complexes with molecular target DNA is of interest for understanding their cytotoxic activities [1-3]. These compounds can bind with DNA duplex through non-covalent interactions, viz intercalation between the bases, surface groove-binding, and 
electrostatic attraction with anionic sugar-phosphate backbones [4]. Based on the interaction of biomolecules and metal complexes, search for new metal-based drugs for cancer treatment has led to an increasing significance for the cytotoxic properties of metal complexes and their mechanisms of action [5, 6]. One of the great accomplishments in the domain of medicinal inorganic chemistry is the introduction of cis-diamminedichloroplatinum(II) (cis-platin) and its successors in the treatment of cancer. However, few of their severe side effects such as renal toxicity, neurotoxicity, myelosuppression, immunosuppression, severe nausea, vomiting, and ototoxicity impelled inorganic chemists to explore new anticancer drugs based on transition metal complexes [7]. Among the various transition metal complexes scrutinized, the ruthenium complexes are the most favorable alternatives in this regard due to their ease of synthesis, advanced chemical and air stability, solubility, rich redox chemistry, structural diversity, and kinetic aspects akin to platinum $[8,9]$. Presently, few ruthenium complexes were entered in clinical trials as anticancer agents [10].

On the other hand, over the past few decades, attention has been made to artificial enzymes, which mimic the structural and functional aspects of naturally occurring enzymes, for utilizing oxidation of organic substrates in the arena of industrial and synthetic processes [11]. In this direction, many catalysts having bio-mimicking activity for various enzymes have been synthesized by chemists. Such artificial enzymes have the same catalytic function, but they are more stable, cost-efficient, and structurally less complex than their natural counterparts. One of the prominent natural catecholase enzymes, a less well-known member of the type-III copper proteins that originate in plant tissues and crustaceans, plays a key role in the oxidation of a wide range of $o$-diphenols (catechol) to the corresponding $o$-quinones $[12,13]$, a process known as catecholase activity. Similarly, hydrolytic reactions, i.e., hydrolysis of phosphodiester bond (phosphodiester cleavage), a process called phosphatase activity, also involves enzyme catalysis. Many research groups are working towards synthesis of enzymes with different materials including metal complexes to imitate the biological functions of above natural enzymes. Recently, our group has reported metal complexes with various ligands [14], which mimic catecholase and phosphatase activities.

Generally, the nature of ligands and chelation decides the properties of the metal complexes. Nowadays, interest is being given to develop thiourea-based ligands that support highly reactive transition metal complexes. $\mathrm{N}, \mathrm{N}$ [(Dialkylamino)(thiocarbonyl)]benzamidine has been observed as a diverse selection of multifunctional thiourea scaffolds that can support metal ions by providing a wide variety of different steric and electronic environments [15, 16]. A new class of tridentate thiocarbanoylbenzamidines containing an additional thiosemicarbazone moiety and their rhenium complexes have been reported recently together with the biological activity of the compounds [17].

Motivated on the above contemplations and with the aim to study transition metal complex interaction on biomolecules, we have synthesized ruthenium(II) complexes containing thiourea ligands (Scheme 1). The interaction studies of ruthenium(II) complex have been performed on selected biomolecules such as calf thymus DNA (CT-DNA) and bovine serum albumin (BSA) to determine the binding mode. The cytotoxic as well as enzyme mimic activities of the complex were also done to understand the biological reactivity preferences.






\section{Results and discussion}

\section{Synthesis and characterization}

The ligand $\mathrm{H}_{2} \mathrm{~L}$ was obtained by simple condensation using our previously reported methodology [18] with crystalline purity and sufficient yield to use without further purification for the complex synthesis. Successively, ruthenium(II) complexes 1, 2 were synthesized in good yields by the reaction of $\mathrm{H}_{2} \mathrm{~L}$ and stable prefabricated ruthenium(II) precursors $\left.\left[\mathrm{RuHCl}(\mathrm{CO})\left(\mathrm{EPh}_{3}\right)_{3}\right)\right](\mathrm{E}=\mathrm{P}$ or As) in $\mathrm{CH}_{3} \mathrm{OH} / \mathrm{CHCl}_{3}$ solvent mixture as shown in Scheme 1. Interestingly, the ligand undergoes hydrolytic $\mathrm{C}=\mathrm{N}$ bond cleavage and coordinates monodentate mode via sulfur of $\mathrm{C}=\mathrm{S}$ group with ruthenium metal.

The new complexes are crystalline solids, non-hygroscopic, air-stable in solution and solid state at room temperature. The complexes were characterized satisfactorily by analytical, spectral (IR, UV-Vis, NMR, and ESI-MS) as well as single crystal $\mathrm{X}$-ray crystallography studies.

\section{Spectroscopic analysis}

The typical IR bands of the new ruthenium(II) complexes were compared with those of the free ligand to find the coordination mode of ligand in complexes. The spectrum of ligand shows three peaks in the range of 3236-3302/ $\mathrm{cm}$ due to $\nu \mathrm{NH}$ groups, whereas in the spectra of complexes the $\nu \mathrm{NH}$ peaks disappeared indicates deprotonation of these groups in ligand on complexation. However, in complexes $\mathbf{1}$ and $\mathbf{2}$ a new broad band was observed in the region at $3379-3381 / \mathrm{cm}$ specified to new $\mathrm{NH}_{2}$ group formed due to $\mathrm{C}=\mathrm{N}$ bond break in the benzamidine ligands [19]. A sharp band appeared range at $820-843 / \mathrm{cm}$ in the spectrum of ligand was assigned to $\nu \mathrm{C}=\mathrm{S}$ group which shifted to lower wave number in complexes $\mathbf{1}$ and 2 upon complex formation. The shift of $\nu \mathrm{C}=\mathrm{S}$ by $20-30$ unit in complexes indicates that the ligand is coordinated to the ruthenium(II) center via the sulfur atom. In addition, the ruthenium(II) complexes show strong vibrations in the anticipated region conform the presence of triphenylphosphine and triphenylarsine. The electronic spectra of ligand and complexes show two-four bands in the region $237-443 \mathrm{~nm}$. The bands in the $237-272 \mathrm{~nm}$ regions can be assigned to $\pi \rightarrow \pi^{*}$ and $n \rightarrow \pi^{*}$ transitions [20]. The absorption maxima located in the $332-339 \mathrm{~nm}$ range were assigned to $\mathrm{S}(p \pi) \rightarrow \mathrm{M}(d \pi)\left(\mathrm{M}=\mathrm{Ru}^{2+}\right) \mathrm{LMCT}$ transition for complexes $\mathbf{1}$ and $\mathbf{2}$. Furthermore, a broad band at 438-443 $\mathrm{nm}$ region in the spectra of complexes have been assigned to $d-d$ transition band of spin-paired $d^{6}$ species with a distorted octahedral structure.
The ${ }^{1} \mathrm{H}$ NMR spectrum of ligand $\mathrm{H}_{2} \mathrm{~L}$ shows three different $\mathrm{NH}$ resonances at 8.10, 8.47, and $12.72 \mathrm{ppm}$. But in $\mathbf{1}$ and $\mathbf{2}$, the peaks for $\mathrm{NH}$ groups were completely disappeared and a new peak appeared around 8.17-8.21 ppm for $-\mathrm{NH}_{2}$ due to ligand $\mathrm{C}=\mathrm{N}$ bond cleavage. The four well separated multiplet resonances at 3.52-3.94 ppm have been assigned to two methylene groups in ligand and its complexes $\mathbf{1}$ and $\mathbf{2}$. Furthermore, appearance of two triplet signals region at $1.15-1.62 \mathrm{ppm}$ were assigned to $\mathrm{N}\left(\mathrm{CH}_{2} \mathrm{CH}_{3}\right)_{2}$ methyl groups in the spectra of ligand and its complexes $[21,22]$. In addition, signals for aromatic protons appear in the expected region. In the ${ }^{13} \mathrm{C}$ NMR spectrum of uncoordinated ligand $\mathrm{H}_{2} \mathrm{~L}$, the $\mathrm{C}=\mathrm{N}$ and $\mathrm{C}=\mathrm{S}$ signals appear around 149.36-155.41 and $187.08-189.61 \mathrm{ppm}$, respectively [23]. In the spectra of $\mathrm{Ru}(\mathrm{II})$ complexes, the signals of the $\mathrm{C}=\mathrm{N}$ carbon disappeared and $\mathrm{C}=\mathrm{S}$ carbon signals shifted to upfield region (169.19-171.69 ppm). These are consistent with the sulfur donor coordination for complexes $\mathbf{1}$ and $\mathbf{2}$ and break of $\mathrm{C}=\mathrm{N}$ bond in benzamidine ligands. The carbonyl carbon resonates at 203.01-204.12 ppm, was comparable with the literature reports. In addition, peaks for $\mathrm{CH}_{2}$ and $\mathrm{CH}_{3}$ carbon were observed region at 13.21-32.61 ppm. Furthermore, the aromatic carbons in the complexes exhibit peaks in the region of $127.62-138.83 \mathrm{ppm}$. The ${ }^{31} \mathrm{P}$ NMR spectrum of complex 1 show a sharp singlet at $34.83 \mathrm{ppm}$ indicates the coordination of two magnetically equivalent triphenylphosphine co ligands in trans position [24]. The mass spectral analysis of complexes $\mathbf{1}, \mathbf{2}$ reveals a signal that corresponds to a molecular ion at $m / z=821.32$, 909.22 , respectively, which is assigned to $[\mathrm{M}-\mathrm{Cl}]^{+}$with an experimental isotope pattern that matches the calculated values.

\section{X-ray crystallographic analysis}

X-ray crystallographic analysis of $\mathbf{1}$ and $\mathbf{2}$ also confirms the metal-induced hydrolytic $\mathrm{C}=\mathrm{N}$ bond break in $\mathrm{H}_{2} \mathrm{~L}$ and formation of unpredicted complexes $\mathbf{1}$ and $\mathbf{2}$. The crystal structure and parameters of complex $\mathbf{1}$ are similar to the previous report of our group in which the ligand undergoes similar hydrolytic cleavage [25]. Hence, here we discuss only the crystal structure of complex 2 in detail (Figs. 1, 2; Table 1). Similar to complex 1, complex 2 also displays an octahedral geometry. The coordination sites are filled up by a $\mathrm{C}=\mathrm{S}$ sulfur atom, a carbonyl group, two chlorine atom and two triphenylarsine trans to each other. The ruthenium atom is in a distorted octahedral environment with trans angles of [As(2)-Ru(1)-As(1)] 176.61(4) ${ }^{\circ}$ and $[\mathrm{Cl}(1)-\mathrm{Ru}(1)-\mathrm{S}(1)] 168.64(8)^{\circ}$. The other two axial sites are occupied by a carbonyl group and one chlorine atom with $\mathrm{Ru}(1)-\mathrm{C}(1)$ and $\mathrm{Ru}(1)-\mathrm{Cl}(1)$ distance of 1.803(10) and 2.573(2) $\AA$. The carbonyl group trans to 


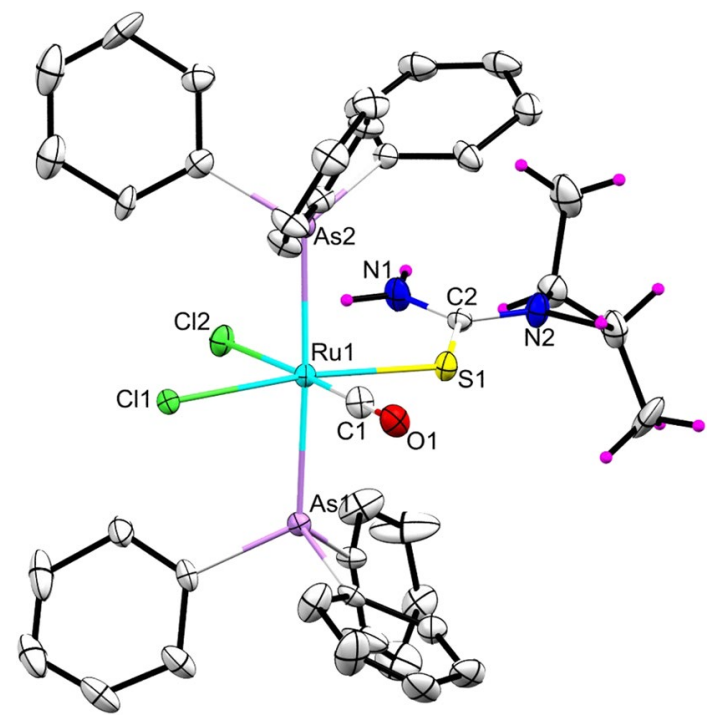

Fig. 1 Perspective view (25\% probability ellipsoids) of complex 2 with the atom numbering scheme. Phenyl rings showed as wire frame

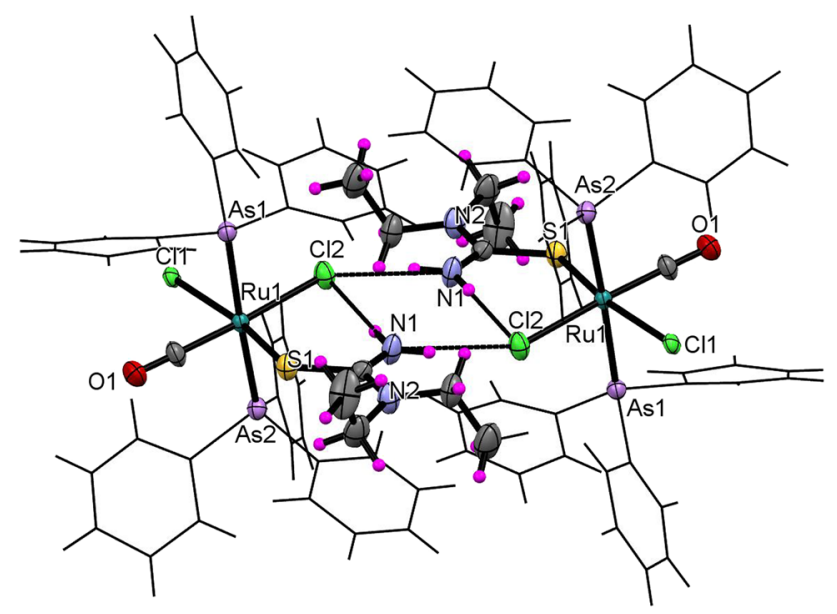

Fig. 2 Weak hydrogen bonding interactions between $\mathrm{Cl}$ and $\mathrm{NH}$ atom in complex 2

the coordinated $\mathrm{Cl}(2)$ atom $[\mathrm{Cl}(2)-\mathrm{Ru}(1)-\mathrm{C}(1)]$ with an angle of $176.3(3)^{\circ}$. This is due to strong $\mathrm{Ru}(\mathrm{II}) \rightarrow \mathrm{CO}$ back donation as showed by the short $\mathrm{Ru}(1)-\mathrm{C}(1)[1.803(10)$ $\AA$ ] bond and low CO stretching frequency $(1952 / \mathrm{cm})$, which prefers $\sigma$ or $\pi$ weak donor groups occupying the site opposite to CO to favor the $d-\pi$ back bonding donation. The second chloride ion attached to the ruthenium ion can be furnished by chloroform solvent [25]. The metal ligand bond distances (Table 2) in the complex 2 agree well with previous reports containing similar coordination environment [26]. Moreover, the complex 2 exhibited weak hydrogen bonding interactions between $\mathrm{Cl}$ and $\mathrm{NH}$ atom.
Table 1 Crystal data and structure refinement for complex 2

\begin{tabular}{|c|c|}
\hline & 2 \\
\hline Empirical formula & $\mathrm{C}_{42} \mathrm{H}_{42} \mathrm{As}_{2} \mathrm{Cl}_{2} \mathrm{~N}_{2} \mathrm{ORuS}$ \\
\hline Formula weight & 944.64 \\
\hline Temperature/K & 293(2) \\
\hline Wavelength/Å & 0.71073 \\
\hline Crystal system & Monoclinic \\
\hline Space group & $P 121 / \mathrm{c} 1$ \\
\hline \multicolumn{2}{|l|}{ Unit cell dimensions } \\
\hline$a / \AA$ & $12.9337(7)$ \\
\hline$b / \AA$ & $18.3880(8)$ \\
\hline$c / \AA$ & $17.7344(7)$ \\
\hline$\alpha /^{\circ}$ & 90 \\
\hline$\beta /^{\circ}$ & $102.314(5)$ \\
\hline$\gamma /^{\circ}$ & 90 \\
\hline Volume $/ \AA^{3}$ & $4120.7(3)$ \\
\hline$Z$ & 4 \\
\hline Density (calcd)/Mg/M $\mathrm{M}^{3}$ & 1.523 \\
\hline Absorption coefficient & $2.189 / \mathrm{mm}$ \\
\hline$F(000)$ & 1904 \\
\hline$\theta$ Range for data collection ${ }^{\circ}$ & $3.313-29.434$ \\
\hline \multirow[t]{3}{*}{ Index ranges } & $-17 \ll h \ll 17$ \\
\hline & $-18 \ll k \ll 25$ \\
\hline & $-23 \ll l \ll 18$ \\
\hline Reflections collected & 22,883 \\
\hline Independent reflections & $9837[R$ (int) $=0.0613]$ \\
\hline Data/restraints/parameters & $9837 / 0 / 462$ \\
\hline Goodness-of-fit on $F^{2}$ & 1.011 \\
\hline Final $R$ indices $[I>2 \sigma(I)]$ & $\begin{array}{l}R 1=0.0843, \\
\mathrm{w} R 2=0.2185\end{array}$ \\
\hline$R$ indices (all data) & $R 1=0.1791, \mathrm{w} R 2=0.2882$ \\
\hline
\end{tabular}

\section{DNA interaction studies}

\section{Fluorescence emissive titration}

Coordination compound and DNA interaction is one of the criterions for comprehending the molecular basis of therapeutic activity or advanced clinical trials. Generally, molecules/ complexes bind non-covalently (intercalation, groove-binding and external electrostatic mode) with DNA. The metal ion, ligands and geometry of the complexes affect the binding efficiency [27]. As a basic testing method, emissive titration study is unanimously employed method to find out the binding mode of metal complexes with DNA which usually involves the changes in emissive intensity and wavelength. Emissive titration experiments were done by aliquot addition of DNA to the test compound and observe the changes in emission intensity. The intercalative mode of affinity between metal complexes and DNA results in hypochromism with or without red/blue shift; on the other hand, non-intercalative/ 
Table 2 Selected bond lengths $(\AA)$ and bond angles $\left({ }^{\circ}\right)$ for complex 2

\begin{tabular}{|c|c|}
\hline 2 & \\
\hline $\mathrm{C}(1)-\mathrm{Ru}(1)$ & $1.803(10)$ \\
\hline $\operatorname{As}(2)-\mathrm{Ru}(1)$ & $2.4750(12)$ \\
\hline $\operatorname{As}(1)-\mathrm{Ru}(1)$ & $2.4844(11)$ \\
\hline $\mathrm{S}(1)-\mathrm{Ru}(1)$ & $2.4096(16)$ \\
\hline $\mathrm{Cl}(1)-\mathrm{Ru}(1)$ & $2.573(2)$ \\
\hline $\mathrm{Cl}(2)-\mathrm{Ru}(1)$ & $2.466(2)$ \\
\hline $\mathrm{As}(1)-\mathrm{Ru}(1)-\mathrm{Cl}(1)$ & $87.34(5)$ \\
\hline $\operatorname{As}(2)-\operatorname{Ru}(1)-\operatorname{As}(1)$ & $176.61(4)$ \\
\hline $\operatorname{As}(2)-\mathrm{Ru}(1)-\mathrm{Cl}(1)$ & $91.54(5)$ \\
\hline $\mathrm{Cl}(2)-\mathrm{Ru}(1)-\mathrm{As}(1)$ & $88.14(8)$ \\
\hline $\mathrm{Cl}(2)-\mathrm{Ru}(1)-\mathrm{As}(2)$ & $88.66(8)$ \\
\hline $\mathrm{Cl}(2)-\mathrm{Ru}(1)-\mathrm{Cl}(1)$ & $90.29(8)$ \\
\hline $\mathrm{S}(1)-\mathrm{Ru}(1)-\mathrm{As}(1)$ & $89.56(8)$ \\
\hline $\mathrm{S}(1)-\mathrm{Ru}(1)-\mathrm{As}(2)$ & $92.14(8)$ \\
\hline $\mathrm{S}(1)-\mathrm{Ru}(1)-\mathrm{Cl}(1)$ & $168.64(8)$ \\
\hline $\mathrm{S}(1)-\mathrm{Ru}(1)-\mathrm{Cl}(2)$ & $100.53(8)$ \\
\hline $\mathrm{C}(1)-\mathrm{Ru}(1)-\mathrm{As}(1)$ & $91.4(4)$ \\
\hline $\mathrm{C}(1)-\mathrm{Ru}(1)-\mathrm{As}(2)$ & $91.7(4)$ \\
\hline
\end{tabular}

electrostatic interaction causes hyperchromism [28]. The fluorescence emission titration curves (Fig. 3) were used to study the binding mode and propensity of complex 2 with CT-DNA in Tris-HCl buffer $(5 \mathrm{mM}$ Tris- $\mathrm{HCl} / 50 \mathrm{mM} \mathrm{NaCl}$ buffer for $\mathrm{pH}=7.2$ ) at $25^{\circ} \mathrm{C}$. Upon increasing concentration of CT-DNA, the emission spectral bands of complex 2 at $323 \mathrm{~nm}$ exhibit hypochromism of about $21.23 \%$ with very small slight red shifts of $0.5 \mathrm{~nm}$. The marked decreases in the fluorescence intensity indicate the intercalative binding mode of complex 2 and DNA. The calculated binding constant $\left(K_{\mathrm{b}}\right)$ value (Table 3 ) is comparable to similar type of previously reported complex [25] and also supports the intercalative mode
Table 3 Fluorescence spectral parameters of ruthenium complexes bound with CT-DNA

\begin{tabular}{llll}
\hline Complex & $K_{\mathrm{b}}$ & $K_{\text {sv }}$ & $K_{\text {app }}$ \\
\hline $\mathbf{1}^{\mathrm{a}}$ & $3.98 \times 10^{4}$ & $1.19 \times 10^{4}$ & $6.30 \times 10^{5}$ \\
$\mathbf{2}$ & $1.06 \times 10^{6}$ & $3.80 \times 10^{4}$ & $1.97 \times 10^{5}$ \\
\hline
\end{tabular}

${ }^{\mathrm{a}}$ Data referred from Ref. [25]

[29]. However, some more experiments require for proving the binding mode.

\section{Fluorescence quenching study}

To gain support for the type of binding of the complex with CT-DNA, the fluorescence quenching studies were performed using metal complex as a quencher. Ethidium bromide (EB) is commonly used as sensitive fluorescent and emits enhanced emissive property in the presence of DNA [30]. From the above info in mind, the quenching of EB bound DNA is calculated with the successive addition of metal complex $\mathbf{2}$. The emission band at $686 \mathrm{~nm}$ for EB displays hypochromism up to $15.52 \%$ with a small red shift from the initial fluorescence intensity (Fig. 4). From this evidence, it is concluded that EB is being released from EB-DNA compound due to the reduction of the corresponding ruthenium complex. The quenching con$\operatorname{stant}\left(K_{\mathrm{sv}}\right)$ value was calculated using classical Stern-Volmer equation according to the previous literature [31], which was listed in Table 3. In addition, the following equation is used to calculate the apparent DNA-binding constant $\left(K_{\text {app }}\right)$ values:

$K_{\mathrm{EB}}[\mathrm{EB}]=K_{\text {app }}\left[M_{50 \%}\right]$,

where $K_{\mathrm{EB}}=1.0 \times 10^{-7} / \mathrm{M}$ is the DNA-binding constant of $\mathrm{EB},[\mathrm{EB}]$ is the concentration of $\mathrm{EB}(7.5 \mu \mathrm{M})$ and $\left[M_{50 \%}\right]$
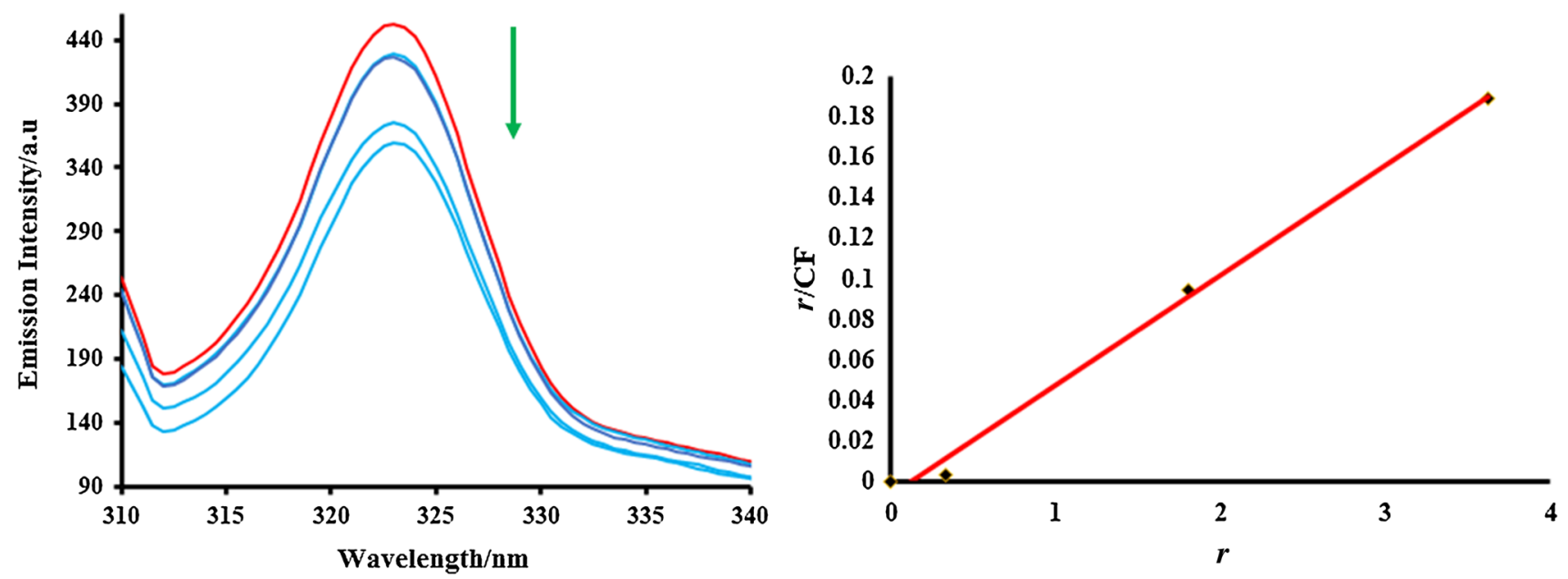

Fig. 3 Emission titrations of complex $2(25 \mu \mathrm{M})$ with CT-DNA $(0-50 \mu \mathrm{M})$ and Scatchard plots of $r / \mathrm{Cf}$ vs $r$ for complex 2 

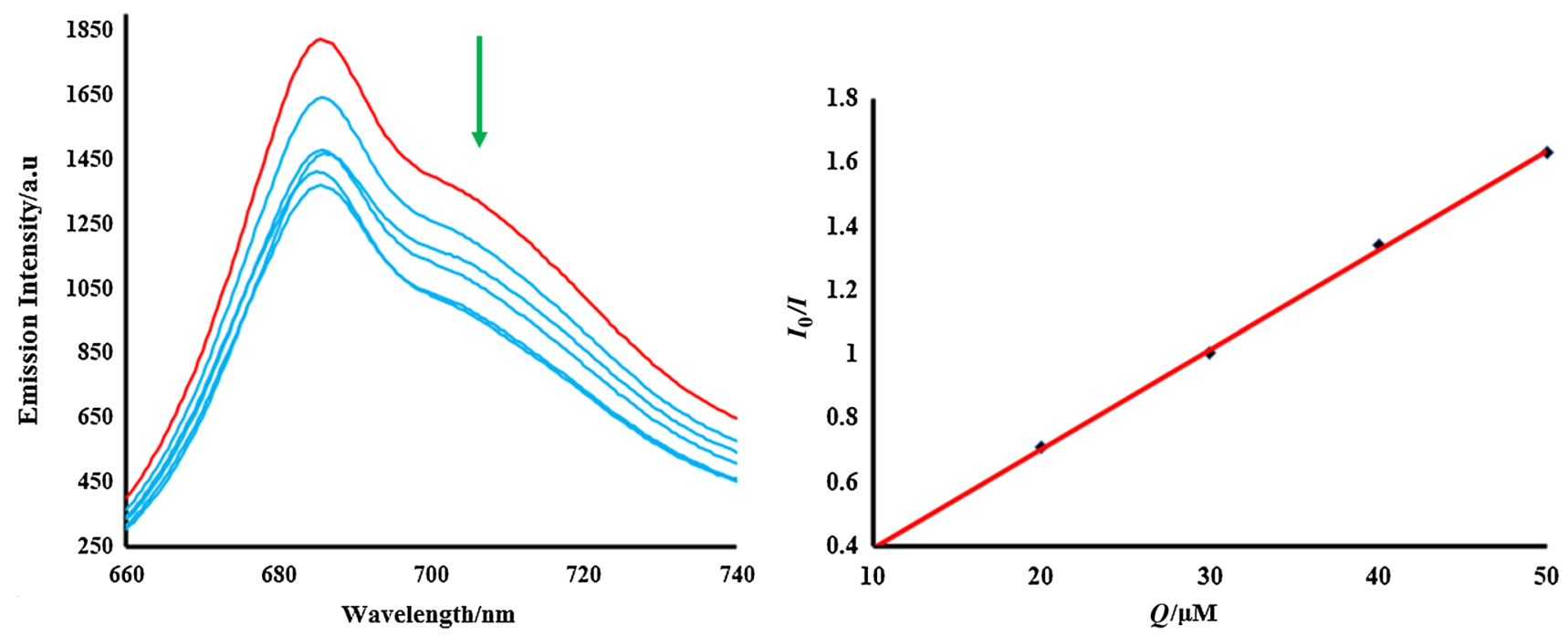

Fig. 4 Emission titrations of complex $2(0-50 \mu \mathrm{M})$ with EB bound CT-DNA $(7.5 \mu \mathrm{M})$ and Scatchard plots of $I_{0} / I$ vs $[Q]$ for complex 2

is the concentration of the compound used to obtain a $50 \%$ reduction in fluorescence intensity of DNA pretreated with EB. The $K_{\text {sv }}$ and $K_{\text {app }}$ values are found to be comparable with our previous reported ruthenium(II) complex [25]. The results support the intercalative binding mode of complex 2 with DNA and the results are consistent with the previous emissive titrations.

\section{Viscosity measurements}

To clarify the binding mode of the $\mathrm{Ru}$ (II) complex with DNA, the viscosity measurements were carried out on CTDNA by varying the concentration of added complex. The experiment involves the measurement of the flow rate of DNA solution through a capillary viscometer. For a small molecule that binds by non-classical intercalation, causes less pronounced or no change in the viscosity of DNA [32]. On the other hand, a classical intercalation mode into DNA causes a significant increase in the viscosity of DNA solution due to increase in the overall DNA molecular length. The plot of $\left(\eta / \eta^{0}\right)^{1 / 3}$ vs [complex]/[DNA] gives a measure of the viscosity changes (Fig. 5). The obtained plot shows increase in the relative viscosity, which clearly indicates intercalate binding mode for complexes. Therefore, we can conclude that the complex 2 binds to CT-DNA in the intercalate regions, which is in accordance with fluorescence spectral results.

\section{Protein binding studies}

The emission studies have also been used to explore the interaction of complex 2 with BSA. BSA $(1 \mu \mathrm{M})$ was titrated with various increasing concentrations of $2(0-50 \mu \mathrm{M})$ in the

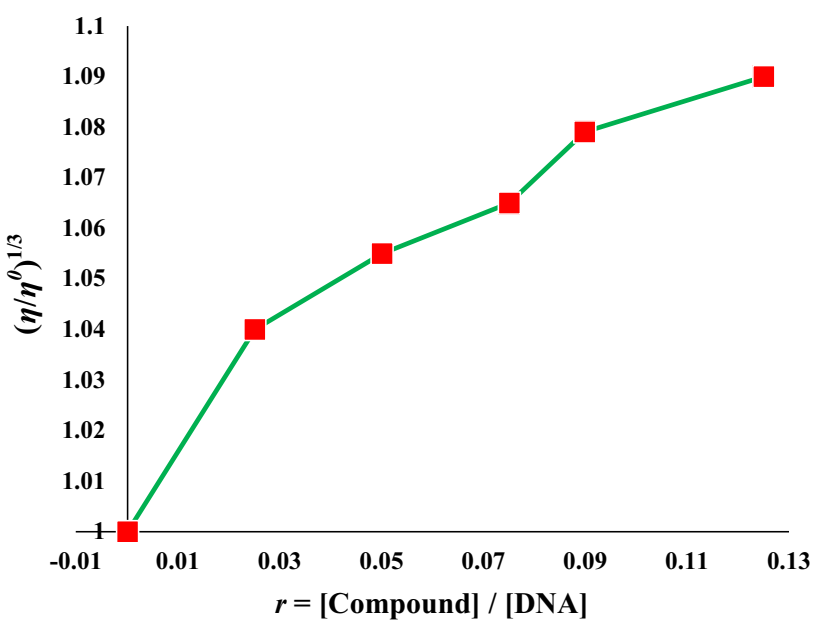

Fig. 5 Relative viscosity $\left(\eta / \eta^{0}\right)^{1 / 3}$ of CT-DNA in Tris-HCl buffer solution in the presence of complex $\mathbf{2}$ at increasing amounts $(r=0-0.12)$

wave length $290-430 \mathrm{~nm}\left(\lambda_{\mathrm{ex}}=280 \mathrm{~nm}\right)$ and their emission spectra recorded. The fluorescence spectrum of BSA exhibits a broad band with a maximum at $340 \mathrm{~nm}$. The outcome of increasing concentration of $\mathbf{2}$ on the emission spectra of BSA at room temperature is shown in Fig. 6a. The value of Stern-Volmer constant $\left(K_{\mathrm{q}}\right)$ calculated from following Stern-Volmer equation [33] is used to express the amount of quenching. Quenching constant $\left(K_{\mathrm{q}}\right)$ was found from the plot of $\log \left(I_{0}-I\right) / I$ vs $\log [\mathrm{Q}]$ (Fig. 6a) which is much higher than the molecular fluorescence diffusing constant as shown in Table 4. The result reveals that the fluorescence quenching mechanism of the compound-BSA system will not be dynamic quenching. It may be static quenching. However, 

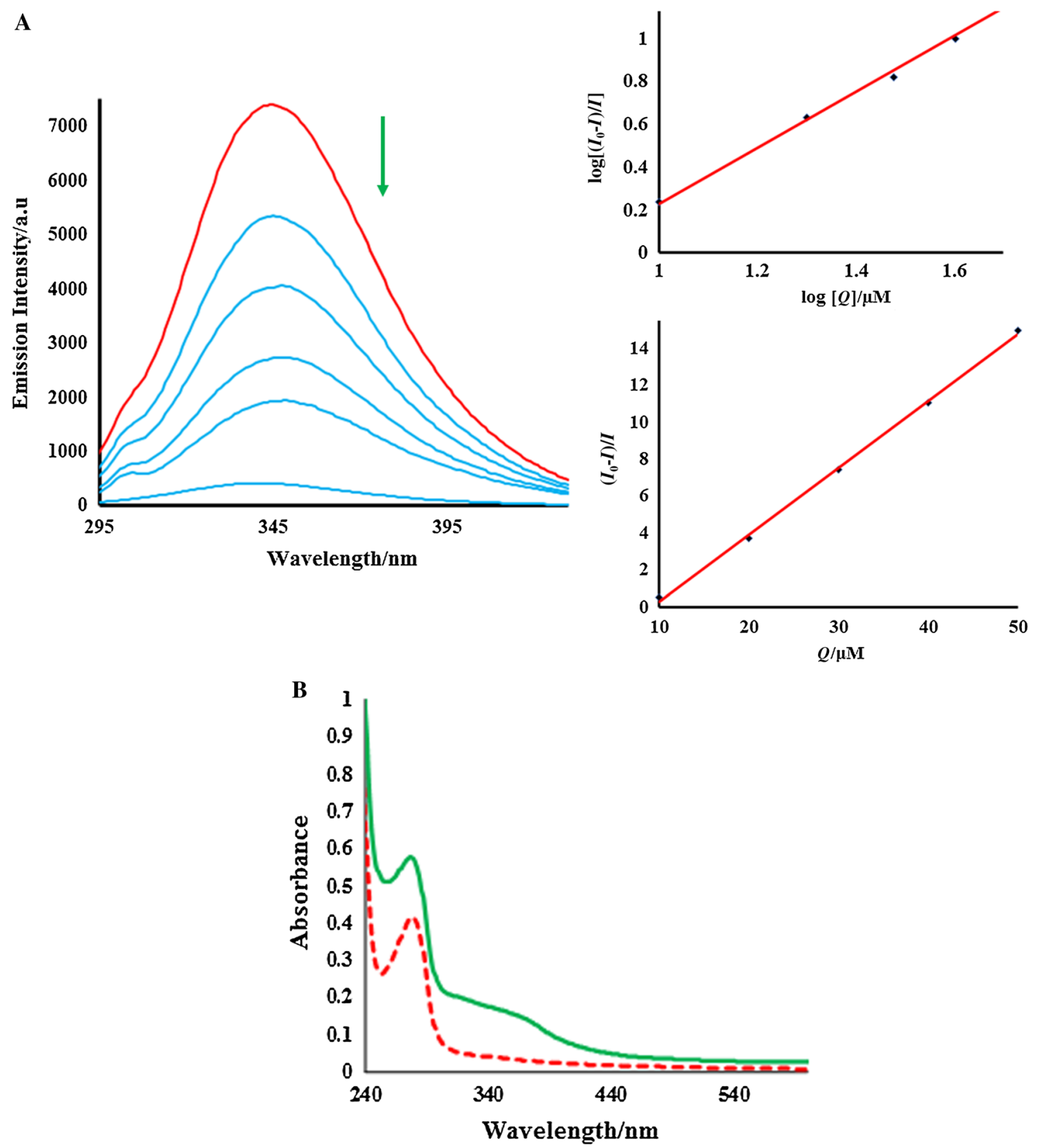

Fig. 6 Emission titrations of complex $2(0-50 \mu \mathrm{M})$ with BSA $(1 \mu \mathrm{M})$ and Stern-Volmer plots of $\left(I_{0}-I\right) / I$ vs. $[Q]$ and Scatchard plots of $\log \left[\left(I_{0}-I\right) / I\right]$ vs. $\log [Q]$ for complex 2 (upper A). Absorbance spec-

this conclusion needs to be confirmed through other experiments. The binding constant $K_{\mathrm{b}}$ was calculated using the Scatchard equation:

$\log \left[\left(I_{0}-I\right) / I\right]=\log K_{\mathrm{b}}+n \log [Q]$,

where $K_{\mathrm{b}}$ is the binding constant of the complex with BSA and $n$ is the number of binding sites. The binding constant $\left(K_{\mathrm{b}}\right)$ has been obtained as per Fig. 6a and its value is given in Table 4 along with $n$. The value of $n$ indicates the availability tra of the complex 2 with BSA [dashed red line-BSA alone; green line-BSA + complex 2] (lower B)

Table 4 Quenching parameters of ruthenium complexes bound with BSA

\begin{tabular}{lllll}
\hline Complex & $K_{\text {sv }}$ & $K_{\mathrm{q}}$ & $K_{\text {bin }}$ & $n$ \\
\hline $\mathbf{1}^{\mathrm{a}}$ & $1.18 \times 10^{5}$ & $1.18 \times 10^{13}$ & $1.03 \times 10^{10}$ & 2.0 \\
$\mathbf{2}$ & $3.62 \times 10^{4}$ & $3.62 \times 10^{12}$ & $1.12 \times 10^{10}$ & 1.3 \\
\hline
\end{tabular}

${ }^{\mathrm{a}}$ Data referred from Ref. [25] 
Table 5 In vitro cytotoxicity of ruthenium complexes in normal and cancer cell lines

\begin{tabular}{|c|c|c|c|}
\hline \multirow[t]{2}{*}{ Complex } & \multicolumn{3}{|l|}{$\mathrm{IC}_{50} / \mu \mathrm{g} / \mathrm{cm}^{3 \mathrm{a}}$} \\
\hline & Vero & HeLa & HepG2 \\
\hline $\mathbf{1}^{\mathrm{c}}$ & $50.60 \pm 0.85$ & $28.69 \pm 1.18$ & $33.65 \pm 1.75$ \\
\hline 2 & $55.12 \pm 0.47$ & $20.16 \pm 1.10$ & $25.39 \pm 0.83$ \\
\hline Cis-platin & $\mathrm{ND}^{\mathrm{b}}$ & $12.29 \pm 1.27$ & $11.78 \pm 1.52$ \\
\hline
\end{tabular}

a $50 \%$ inhibitory concentration after exposure for $24 \mathrm{~h}$ in the MTT assay

${ }^{\text {b No data }}$

${ }^{\mathrm{c}}$ Data referred from Ref. [25]

of one binding site in BSA for complex 2 . The higher values of $K_{\mathrm{q}}$ and $K_{\mathrm{b}}$ signify a strong interaction between the BSA proteins. The quenching parameters for complex 2 are comparable to similar type of previously reported complex [25]. Furthermore, the static quenching fluorescence mechanism of the compound is proved by UV-Vis absorption spectral studies. Generally, quenching happens either by dynamic or static ways. When the fluorophore and the quencher come into contact during the transient existence of the excited state, dynamic quenching occurs [34]. On the other hand, static quenching represents to the formation of fluorophore-quencher compound in the ground state. UV-Vis absorption spectra of BSA have been measured in the absence and presence of 2 . Figure $6 \mathrm{~b}$ shows that addition of $\mathbf{2}$ to a fixed concentration of BSA leads to an increase in the absorbance of the BSA absorption peak at $280 \mathrm{~nm}$ with a small blue shift for free BSA, indicating that the complex 2 interact with BSA by the static quenching which could be attributed to the formation of the ground state complex as reported earlier [35].

\section{In vitro cytotoxicity assay}

The ruthenium complex was evaluated for its cytotoxicity vs a pair of human tumor cell lines such as human cervical cancer (HeLa), human hepatocellular carcinoma (HepG2), and normal Vero cells by means of a colorimetric assay (MTT assay) that measures mitochondrial enzyme succinate dehydrogenase activity as an indication of cell viability. Cis-platin was used as the reference compound to evaluate the cytotoxic activity. The results were analyzed by cell viability curves and expressed with $\mathrm{IC}_{50}$ values of complex 2 in Table 5. The amount of cell proliferation significantly decreases in various concentration ranges $\left(10-100 \mu \mathrm{g} / \mathrm{cm}^{3}\right)$ on supplementation with complex, as observed within $24 \mathrm{~h}$ of incubation with respective of above cell lines.

From $\mathrm{IC}_{50}$ values, the complex demonstrates notable activity in human cervical cancer (HeLa), human hepatocellular carcinoma (HepG2) cell lines. However, the complex
Scheme 2

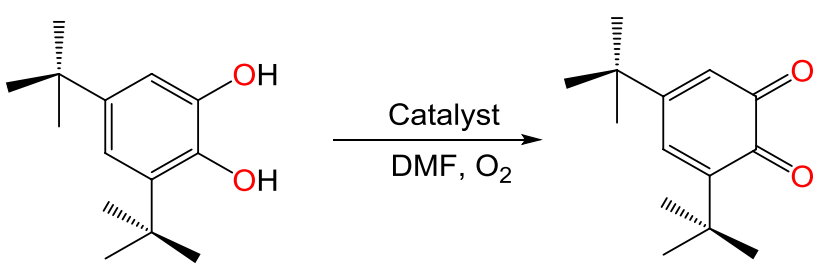

shows marginally less activity than cis-platin and comparable activity with previously reported ruthenium complexes $[10,23,25,26]$. It is noteworthy that the complex $\mathbf{2}$ is less toxic towards the normal Vero cell line as is evident from the $\mathrm{IC}_{50}$ values.

\section{Enzyme mimicking studies}

\section{Catecholase activity}

3,5-Di-tert-butylcatachol (3,5-DTBC) was used as substrate to study the catecholase mimic activity of the complex $\mathbf{2}$. Due to the presence of two bulky tert-butyl substituents, the substrate shows a low quinine-catechol reduction potential and hence effortless oxidation occurs to the corresponding $o$-quinone (Scheme 2).

The stable oxidation product 3,5-di-tert-butylquinone (3,5-DTBQ) displays a maximum emission at $390 \mathrm{~nm}$. Before proceeding to a thorough kinetic study, the complex $\mathbf{2}\left(1 \times 10^{-4} \mathrm{M}\right)$ were examined by addition of complex $\mathbf{2}$ to a 100 equivalents DMF solution of 3,5-DTBC $\left(1 \times 10^{-2} \mathrm{M}\right)$ under oxygen atmosphere and the progress of the reaction was monitored for every $15 \mathrm{~min}$ interval up to $2 \mathrm{~h}$. Owing to addition of the catecholic substrate, a new band (Fig. 7) appeared at $434 \mathrm{~nm}$ and its intensity steadily increased may be due to ligand to metal charge transfer band of the oxidized product 3,5-di-tert-butylbenzoquinone (3,5-DTBQ). Therefore, the experiment obviously demonstrates that the oxidation of 3,5-DTBC to 3,5-DTBQ was catalyzed by $\mathbf{2}$, as it is well known that 3,5-DTBQ displays a maximum at $\lambda_{\text {emis }}=434 \mathrm{~nm}$ in DMF. The catalytic performance exhibits saturation kinetics based on the Michaelis-Menten model appeared to be suitable under excess substrate conditions. Plots of $k_{i}$ vs [3,5-DTBC] provided non-linear curve of decreasing slope (Fig. 7) which are best designated kinetic equation by our earlier report [25]. The Michaelis-Menten constant $\left(K_{\mathrm{m}}\right)$ and maximum initial rate $\left(V_{\text {max }}\right)$ were determined by linearization using Lineweaver-Burk plots (Fig. 7). The turnover number values $\left(K_{\text {cat }}\right)$ were obtained by dividing the $V_{\max }$ values by the concentration of the complex and all these parameters are listed in Table 6. The results unambiguously demonstrate that the complex $\mathbf{2}$ is active towards the oxidation of 3,5-DTBC. When compared to similar reported complex, the activity of the present complex is slightly lower 

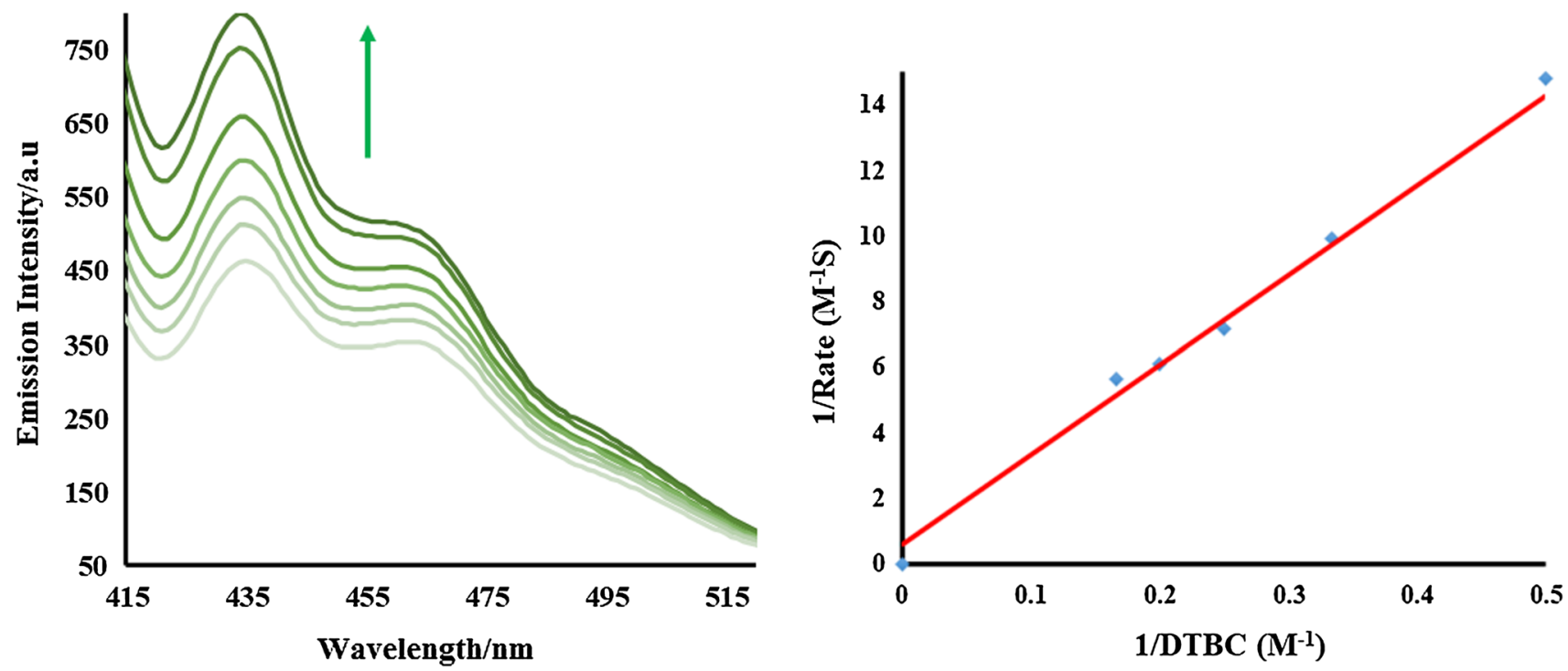

Fig. 7 Oxidation of 3,5-DTBC by complex 2 monitored by emission spectroscopy and Lineweaver-Burk plot for complex 2

Table 6 Kinetic parameters for catecholase and phosphatase activity of ruthenium complexes

\begin{tabular}{lllc}
\hline Catalyst & $K_{\mathrm{m}} / \mathrm{M}$ & $V_{\text {max }} / \mathrm{M} \mathrm{m}^{1}$ & $K_{\text {cat }} / \mathrm{h}^{-1}$ \\
\hline $\mathbf{1}(3,5-\mathrm{DTBC})^{\mathrm{a}}$ & $9.88 \times 10^{-1}$ & $2.85 \times 10^{-2}$ & 988 \\
$\mathbf{1}(4-\mathrm{NPP})^{\mathrm{a}}$ & $4.26 \times 10^{-3}$ & $1.01 \times 10^{-3}$ & 85 \\
$\mathbf{2}(3,5-\mathrm{DTBC})$ & $3.74 \times 10^{-3}$ & $1.58 \times 10^{-3}$ & 374 \\
$\mathbf{2}(4-\mathrm{NPP})$ & $5.69 \times 10^{-4}$ & $1.23 \times 10^{-4}$ & 569 \\
\hline
\end{tabular}

${ }^{a}$ Data referred from Ref. [25]

although it possesses appreciable catecholase mimic activity [25]. From all the data, it is concluded that the catalytic oxidation follows the mechanism suggested by Chyn and Urbach [36].

\section{Phosphatase activity}

Based on the promising catecholase activity result, the complex was further investigated for its phosphatase activity. Phosphate esters play several important functions in biological systems such as information storage (DNA/RNA), cellular signaling (cAMP), and energy transduction (ATP) [11]. The phosphodiester bonds in these molecules are extremely resistant towards hydrolysis because of the repulsion between the negatively charged backbone and potential nucleophiles. Since the compound 4-nitrophenyl phosphate disodium salt hexahydrate (4-NPP) ester is negatively charged and under neutral conditions they are very resistant to hydrolysis, was selected as substrate. The 4-NPP hydrolysis was monitored using complex $\mathbf{2}$ as catalyst by emissive titrations (Fig. 8) on the time evolution of 4-NP in DMF at $\lambda_{\text {emis }}=486 \mathrm{~nm}\left(\lambda_{\text {ex }}=435 \mathrm{~nm}\right)$ over 15 min break up to $2 \mathrm{~h}$ with 40 equivalents of the substrate (Scheme 3 ).

The dependence of the initial rate on the concentration of the substrate was monitored at the respective wavelength by emission spectroscopy, which corresponds to the increase in 4-nitrophenolate (4-NP) concentration (Fig. 8). The rate vs concentration of substrate data were analyzed based on Michaelis-Menten approach of enzymatic kinetics to get the Lineweaver-Burk (double reciprocal) plot as well as the values of variety of kinetic parameters $V_{\max }, K_{\mathrm{m}}$ and $K_{\text {cat }}$. Plot of $k_{i}$ vs [4-NPP] gave non-linear curve of decreasing slope which is best designated by the first-order kinetic equation.

The turnover number value $\left(K_{\text {cat }}\right)$ was obtained by dividing the $V_{\max }$ value by the concentration of the complex and all the parameters are listed in Table 6. The results show that the complex 2 owns superior activity and effectively catalyze the hydrolysis with appreciable turnover rate [25]. Moreover, the kinetic data reveal that the hydrolysis of 4-NPP followed the mechanism described earlier [25].

\section{Conclusions}

In conclusion, the ruthenium complexes 1 and 2 bearing thiourea ligand have been synthesized and characterized by analytical, spectral, and single crystal X-ray crystallographic techniques. The characteristic results reveal the $\mathrm{C}=\mathrm{N}$ bond cleavage in ligands and monodentate coordination via $\mathrm{C}=\mathrm{S}$ group with the ruthenium metal ion. The results of single crystal XRD analysis of complexes confirm ligand cleavage, monodentate coordination mode and octahedral geometry. The binding properties of the ruthenium complex with 

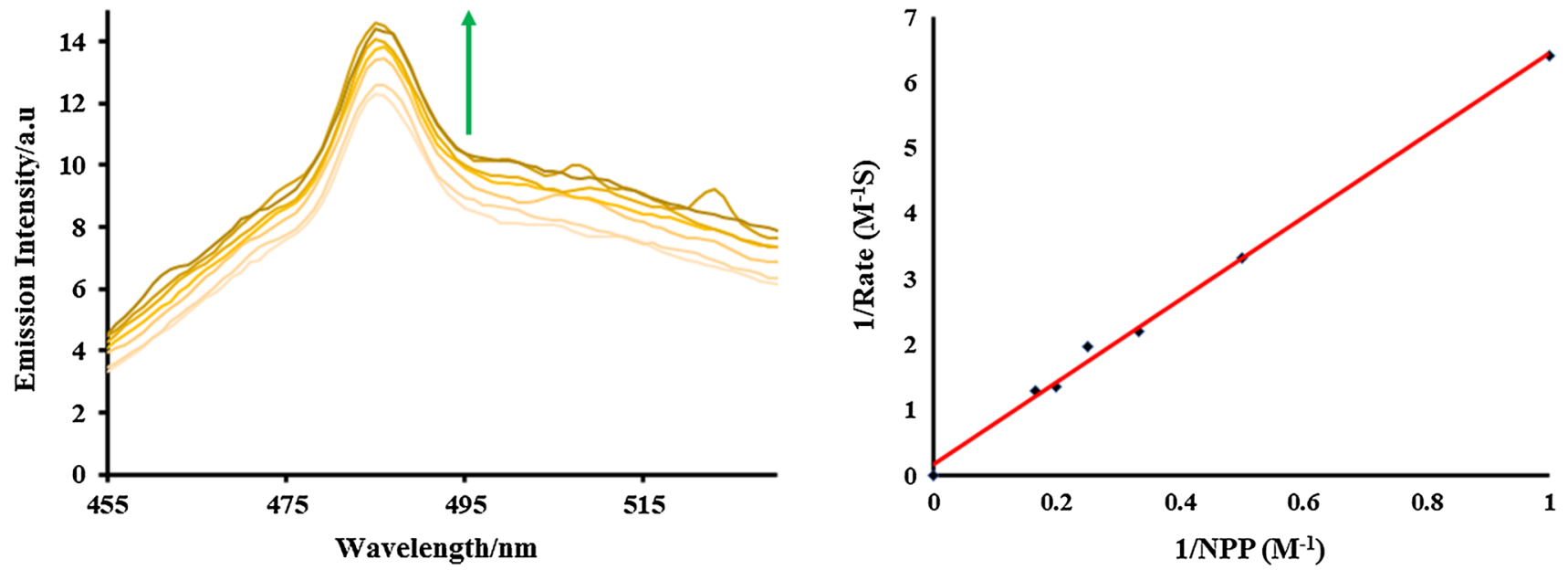

Fig. 8 Hydrolysis of 4-NPP by the complex 2 monitored by emission spectroscopy and Lineweaver-Burk plot for complex 2

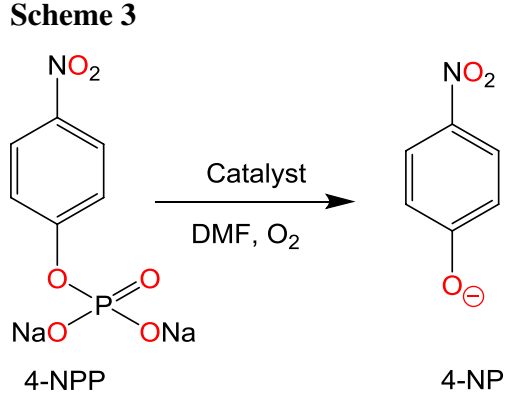

CT-DNA were evaluated by emissive titrations, fluorescence quenching, viscosity measurements, and the results show that the complex interacts with CT-DNA through intercalative mode. Furthermore, the complex BSA protein interactions were examined by $\mathrm{UV}-\mathrm{V}$ is and emissive titrations reveal that complex has shown high binding affinity and acts as static quencher. The in vitro cytotoxic study demonstrates the substantial cytotoxicity of the complex. Moreover, the complex was effectively used for aerial oxidation of catechol and phosphate hydrolysis. On the basis of Michaelis-Menton approach of enzyme kinetics, the complex shows good catalytic efficiency in catechol-oxidase functional mimic in the conversion of 3,5-DTBC to 3,5-DTBQ and ester hydrolysis functional mimic in the hydrolysis of 4-NPP to 4-NP in aerobic conditions.

\section{Experimental}

All chemicals were procured commercially and used as received. Solvents were dried and distilled following the literature procedures [37] and reactions carried out under room temperature. Microanalyses were performed using an apparatus designed by Technico Instuments, India. Vario EL
III CHNS analyzer was used for elemental analysis measurement. Bruker FT IR spectrophotometer equipped with an ATR sampling accessory was employed for recording IR spectra in the range $4000-450 / \mathrm{cm}$. UV-Vis spectra were recorded on Shimadzu UV-1650 PC spectrophotometer over 800-200 nm range. ${ }^{1} \mathrm{H},{ }^{13} \mathrm{C},{ }^{31} \mathrm{P}$ NMR spectra were performed on a Bruker Ultra Shield using DMSO- $d_{6}$ and $\mathrm{CDCl}_{3}$ as solvent. The chemical shifts are given in ppm relative to $\mathrm{SiMe}_{4}$ and orthophosphoric acid. ESI-MS were recorded on a Q-TOF micro ${ }^{\mathrm{TM}}$ mass spectrometer operating in ESI mode. Buffer solutions were prepared using doubly distilled water. Stock solution of complex (1 $\mathrm{mM}$ in DMSO) was stored at $4{ }^{\circ} \mathrm{C}$ and used whenever required. Data were expressed as the mean \pm the standard deviation from three independent experiments. The ruthenium precursors $[\mathrm{RuHCl}(\mathrm{CO})$ $\left.\left(\mathrm{EPh}_{3}\right)_{3}\right](\mathrm{E}=\mathrm{As}$ or $\mathrm{P})$ and the ligand $(N-(N, N$-diethylaminothiocarbonyl)benzimidoylchloride-2-aminoacetophenone$\mathrm{N}$-methylthiosemicarbazone $)\left(\mathrm{H}_{2} \mathrm{~L}\right)$ were prepared according to literature methods $[18,38]$.

\section{Synthesis of complexes 1 and 2}

The metal complexes were prepared as per reported procedure with minor alteration [39]. $\left[\mathrm{RuHCl}(\mathrm{CO})\left(\mathrm{EPh}_{3}\right)_{3}\right](\mathrm{E}=\mathrm{P}$ or As) (1 mmol) and the ligand $\mathrm{H}_{2} \mathrm{~L}(1 \mathrm{mmol})$ were dissolved in $10 \mathrm{~cm}^{3}$ of methanol and chloroform solvent mixture $(1: 1$ ratio). The solution mixture was mildly heated under reflux for $12 \mathrm{~h}$. The progress of the reaction was monitored by thin layer chromatography (TLC) using 9:1 mixture of petroleum ether-ethyl acetate mixture as mobile phase. After completion of the reaction, the resulting solution was filtered and the filtrate was left untroubled for slow evaporation of the solvent. After 5 days, brown colored crystals suitable for $\mathrm{X}$-ray diffraction were obtained. 
Carbonyldichlorido(1,1-diethylthiourea)-bis(triphenylphosphine)ruthenium(II) (1) The analytical and spectral data are identical to the previously reported complex [25].

Carbonyldichlorido(1,1-diethylthiourea)bis(triphenylarsine)ruthenium(II) $\left(2, \mathrm{C}_{42} \mathrm{H}_{42} \mathrm{As}_{2} \mathrm{Cl}_{2} \mathrm{~N}_{2} \mathrm{O}_{2} \mathrm{RuS}\right)$ Yield: 54\%; color: brown; IR $(\mathrm{KBr}):=3380\left(\mathrm{NH}_{2}\right), 1939(\mathrm{C} \equiv \mathrm{O}), 829(\mathrm{C}=\mathrm{S}) /$ $\mathrm{cm} ;{ }^{1} \mathrm{H}$ NMR $\left(300.13 \mathrm{MHz}, \mathrm{CDCl}_{3}\right): \delta=8.21\left(\mathrm{~s}, \mathrm{NH}_{2}\right)$, 7.21-7.80 (m, aromatic), 3.11 (q, $J=7.0 \mathrm{~Hz}, 2 \mathrm{H}, \mathrm{CH}_{2}$ ), $3.02\left(\mathrm{q}, J=7.0 \mathrm{~Hz}, 2 \mathrm{H}, \mathrm{CH}_{2}\right), 1.40\left(\mathrm{t}, J=7.0 \mathrm{~Hz}, 3 \mathrm{H}, \mathrm{CH}_{3}\right.$ ), $1.37\left(\mathrm{t}, J=7.0 \mathrm{~Hz}, 3 \mathrm{H}, \mathrm{CH}_{3}\right) \mathrm{ppm} ;{ }^{13} \mathrm{C} \mathrm{NMR}(300.13 \mathrm{MHz}$, $\left.\mathrm{CDCl}_{3}\right): \delta=202.12(\mathrm{C} \equiv \mathrm{O}), 172.14(\mathrm{C}=\mathrm{S}), 126.64(\mathrm{Ar}$ C), 119.24 ( $\mathrm{Ar} \mathrm{C}$ ), 118.71 ( $\mathrm{Ar} \mathrm{C}), 112.41$ (Ar C), 46.95 $\left(\mathrm{CH}_{2}\right), 45.92\left(\mathrm{CH}_{2}\right), 14.32\left(\mathrm{CH}_{3}\right), 13.94\left(\mathrm{CH}_{3}\right) \mathrm{ppm}$; UVVis $\left(\mathrm{CHCl}_{3}\right): \lambda_{\max }(\varepsilon)=238(44,200), 266(27,000), 339$ $(12,540), 443(5240) \mathrm{nm}\left(\mathrm{dm}^{3} / \mathrm{mol} / \mathrm{cm}\right)$; ESI-MS: $\mathrm{m} / z$ calcd. 944.68, found $909.22\left([\mathrm{M}-\mathrm{Cl}]^{+}\right)$.

\section{X-ray structure determination}

Crystals of complexes suitable for single crystal XRD were grown from slow evaporation of methanol-chloroform solvent mixture (CCDC reference number 1584536). Suitable single crystal of compounds with accurate dimensions was mounted on a glass fiber containing epoxy cement. Crystal data were collected on Gemini Ultra diffractometer. Structure solutions and refinements of the compounds were done using the programs SHELXS-14 [40]. Refinement and all further calculations were carried out using SHELXL. All non-solvent heavy atoms were refined anisotropically. All non-solvent hydrogen atoms were idealized using the standard SHELXL idealization methods [41]. When the nonhydrogen atoms will be refined by anisotropically, using weighted full-matrix least squares on F2. Atomic scattering factors were incorporated in the computer programs.

\section{DNA-binding studies}

The binding interaction experiments of complex with CTDNA in double distilled water containing $95 \%$ Tris/ $/ \mathrm{NaCl}$ buffer (5 mM Tris- $\mathrm{HCl} / 50 \mathrm{mM} \mathrm{NaCl}$ buffer, $\mathrm{pH}$ 7.2) were carried out using a Fluoromax spectrofluorometer with a rectangular quartz cuvette of $1 \mathrm{~cm}$ path length. Stock solutions of CT-DNA used in the studies not ever exceeded 5\% DMSO $(v / v)$ in the final volume. A stock solution of CT-DNA was stored at $277 \mathrm{~K}$ and used after no more than 4 days. Tris- $\mathrm{HCl}$ buffer solution was used to base line correction. The excitation wavelength was fixed by the emission range and attuned before measurements. The emissive titration experiments were performed using a fixed concentration $(25 \mu \mathrm{M})$ of test compounds to which increments of the $(0-10 \mu \mathrm{M})$ DNA stock solution were added. The emission intensities were recorded for complexes in the range of 300-600 nm. Titrations were manually done by a micropipette for the addition of CT-DNA and reference solution to eliminate the absorbance of CT-DNA itself. Further support for the relative binding property of complexes binding to DNA via intercalation is given through emission quenching experiments. DNA was pretreated with ethidium bromide (EB) for $30 \mathrm{~min}$. Then the test solutions were added to the mixture of EB-DNA, and the change in the fluorescence intensity was measured. The excitation and the emission wavelength were $510 \mathrm{~nm}$ and $604 \mathrm{~nm}$, respectively. EB was non-emissive in buffer solution ( $\mathrm{pH}$ 7.2) due to fluorescence quenching of the free EB by solvent. In the fluorescence quenching spectra, the reduction in emission intensity measured the binding mode of complexes to CT-DNA.

Viscosity experiments were carried out using an Ubbelodhe viscometer at a constant temperature $\left(30.0 \pm 0.1{ }^{\circ} \mathrm{C}\right)$ in a thermostat and the relative parameters were calculated from the relation $\eta=\left(t-t_{\mathrm{o}}\right) / t_{\mathrm{o}}$, where $t$ is the observed flow time of DNA-containing solution and $t_{\mathrm{o}}$ is the flow time of Tris- $\mathrm{HCl} / \mathrm{NaCl}$ buffer alone. Data were presented as $(\eta /$ $\left.\eta^{0}\right)^{1 / 3}$ vs binding ratio $(r=[$ Compounds $] /[\mathrm{DNA}]=0.0-0.1)$, where $\eta$ is the viscosity of CT-DNA in the presence of the compound, and $\eta^{0}$ is the viscosity of CT-DNA alone.

\section{Protein binding studies}

The excitation wavelength of BSA at $280 \mathrm{~nm}$ and the emission at $345 \mathrm{~nm}$ were monitored for the protein binding studies using fluorescence spectra recorded with synthesized compounds. The excitation wavelength of BSA at $280 \mathrm{~nm}$ and the quenching of the emission intensity of tryptophan residues of BSA at $346 \mathrm{~nm}$ were monitored using the complexes as quenchers with increasing concentrations. The excitation and emission slit widths (each $5 \mathrm{~nm}$ ) remained constant for all the experiments. A scan rate of $200 \mathrm{~nm} / \mathrm{min}$ was used. Samples were carefully degassed using pure nitrogen gas for $15 \mathrm{~min}$. Stock solution of BSA was prepared in $50 \mu \mathrm{M}$ phosphate buffer ( $\mathrm{pH}$ 7.2) and stored in the dark at $4{ }^{\circ} \mathrm{C}$ for further use. Furthermore, the type of quenching mechanism of complexes was determined from the UV-Vis absorption spectra in the range of $200-600 \mathrm{~nm}$.

\section{In vitro anticancer activity: 3-[4,5-dimethylthiazol-2-yl]2,5-diphenyltetrazolium bromide (MTT) assay}

The human cervical cancer (HeLa), human hepatocellular carcinoma (HepG2) were obtained from National Centre for Cell Science (NCCS), Pune and grown in Eagles Minimum Essential Medium containing 10\% fetal bovine serum (FBS). The cells were maintained at $37{ }^{\circ} \mathrm{C}, 95 \%$ air and $100 \%$ relative humidified atmosphere. The cytotoxicity of 
the investigated ruthenium(II) complex in comparison to cisplatin was determined using the MTT assay. The MTT colorimetric assay is based on the measurement of mitochondrial enzyme succinate dehydrogenase activity, as an indication of cell viability. MTT is a yellow water-soluble tetrazolium salt. A mitochondrial enzyme in living cells, succinate dehydrogenase, cleaves the tetrazolium ring, converting the MTT to an insoluble purple formazan. Therefore, the amount of formazan produced is directly proportional to the number of viable cells. After $48 \mathrm{~h}$ of incubation, $15 \mu \mathrm{M}$ of MTT $\left(5 \mathrm{mg} / \mathrm{cm}^{3}\right)$ in phosphate buffered saline (PBS) was added to each well and incubated at $37^{\circ} \mathrm{C}$ for $4 \mathrm{~h}$. The medium with MTT was then flicked off and the formed formazan crystals were solubilized in $100 \mu \mathrm{M}$ of DMSO and then measured the absorbance at $570 \mathrm{~nm}$ using microplate reader. One hundred microliters per well of cell suspension were seeded into 96-well plates at plating density of 10,000 cells/well and incubated to allow for cell attachment at $37{ }^{\circ} \mathrm{C}, 5 \% \mathrm{CO}_{2}$, $95 \%$ air, and $100 \%$ relative humidity. After $24 \mathrm{~h}$ the cells were treated with serial concentrations of the test samples. They were initially dissolved in DMSO and an aliquot of the sample solution was diluted to twice the desired final maximum test concentration with serum free medium. Additional four serial dilutions were made to provide a total of five sample concentrations. Aliquots of $100 \mathrm{~mm}^{3}$ of these different sample dilutions were added to the appropriate wells already containing $100 \mathrm{~mm}^{3}$ of medium, resulting in the required final sample concentrations. Following sample addition, the plates were incubated for an additional $48 \mathrm{~h}$ at $37{ }^{\circ} \mathrm{C}, 5 \% \mathrm{CO}_{2}, 95 \%$ air, and $100 \%$ relative humidity. The medium containing without samples was served as control and triplicate was maintained for all concentrations. Nonlinear regression graph was plotted between $\%$ cell inhibition and log concentration and $\mathrm{IC}_{50}$ was determined using Graph Pad Prism software.

\section{Enzyme kinetic studies}

The kinetics for the oxidation of catalytic oxidation of 3,5-ditertbutylcatechol (3,5-DTBC) and the hydrolysis of 4-nitrophenyl phosphate (4-NPP) were monitored by fluorescence spectra under pseudo first-order kinetic reaction. 100 equivalents of 3,5-DTBC and 40 equivalents of 4-NPP in DMF $\left(10^{-3} \mathrm{M}\right)$ were added to $10^{-4} \mathrm{M}$ solutions of ruthenium(II) complex under aerobic conditions. Emissive intensity of the resultant reaction mixture was plotted with respect to wavelength at a regular interval of 15 min using a fluorescence spectrophotometer in the range 410-700 nm. The dependence of the rate on substrate concentration and diverse kinetic parameters were obtained by treatment of complexes with 3,5-DTBC and 4-NPP monitoring the increase in emission intensity at 435 and $485 \mathrm{~nm}$, respectively (the peak corresponding to the band maxima), as a function of time.

Acknowledgements Open access funding provided by TU Wien (TUW). The authors thank UGC, India for financial assistance to Department of Chemistry, Periyar University, Salem under SAP (no. 540/20/DRS-I/2016(SAP-I)).

Open Access This article is distributed under the terms of the Creative Commons Attribution 4.0 International License (http://creativeco mmons.org/licenses/by/4.0/), which permits unrestricted use, distribution, and reproduction in any medium, provided you give appropriate credit to the original author(s) and the source, provide a link to the Creative Commons license, and indicate if changes were made.

\section{References}

1. Alderden RA, Hall MD, Hambley TW (2006) J Chem Educ 83:728

2. Kelland L (2007) Nat Rev Cancer 7:573

3. Breydo L, Uversky VN (2011) Metallomics 3:1163

4. Barry NPE, Sadler PJ (2013) Chem Commun 49:5106

5. Li VS, Choi D, Wang Z, Jimenez LS, Tang MS, Kohn H (1996) J Am Chem Soc 18:2326

6. Zuber G, Quada JC, Hecht SM (1998) J Am Chem Soc 120:9368

7. Liu JG, Ye BH, Li H, Zhen QX, Ji LN, Fu YH (1999) J Inorg Biochem 76:265

8. Santini C, Pellei M, Gandin V, Porchia M, Tisato F, Marzano C (2014) Chem Rev 114:815

9. Suess-Fink G (2010) Dalton Trans 39:1673

10. Vijayan P, Viswanathamurthi P, Sugumar P, Ponnuswamy MN, Balakumaran MD, Kalaichelvan PT, Velmurugan K, Nandhakumar R, Butcher RJ (2015) Inorg Chem Front 2:620

11. Sanyal R, Guha A, Ghosh T, Mondal TK, Zangrando E, Das D (2014) Inorg Chem 53:85

12. Mukherjee J, Mukherjee R (2002) Inorg Chim Acta 337:429

13. Neves A, Rossi LM, Bortoluzzi AJ, Szpoganicz B, Wiezbicki C, Schwingel E (2002) Inorg Chem 41:1788

14. Gomathi A, Vijayan P, Viswanathamurthi P, Suresh S, Nandhakumar R, Hashimoto T (2017) J Coord Chem 70:1645

15. Nguyen HH, Abram U (2009) Eur J Inorg Chem 3179

16. Nguyen HH, Abram U (2007) Inorg Chem 46:5310

17. Castillo Gomez JD, Hagenbach A, Gerling-Driessen UIM, Koksch B, Beindorff N, Brenner W, Abram U (2017) Dalton Trans 46:14602

18. Vijayan P, Viswanathamurthi P, Velmurugan K, Nandhakumar R, Balakumaran MD, Malcki JG (2015) RSC Adv 5:103321

19. Barandov A, Abram U (2009) Inorg Chem 48:8072

20. Manikandan R, Anitha P, Prakash G, Vijayan P, Viswanathamurthi P (2014) Polyhedron 81:619

21. Nguyen HH, Pham CT, Abram U (2015) Inorg Chem 54:5949

22. Maia PIS, Nguyen HH, Hagenbach A, Bergemann S, Gust R, Deflon VM, Abram U (2013) Dalton Trans 42:5111

23. Sathiya Kamatchi T, Chitrapriya N, Lee H, Fronczek CF, Fronczek FR, Natarajan K (2012) Dalton Trans 41:2066

24. Manikandan R, Anitha P, Prakash G, Vijayan P, Viswanathamurthi P, Butcher RJ, Malecki JG (2015) J Mol Catal A Chem 398:312

25. Vijayan P, Viswanathamurthi P, Sugumar P, Ponnuswamy MN, Malecki JG, Velmurugan K, Nandhakumar R, Balakumaran MD, Kalaichelvan PT (2017) Appl Organometal Chem 31:e3652 
26. Kalaivani P, Prabhakaran R, Poornima P, Dallemer F, Vijayalakshmi K, Vijaya Padma V, Natarajan K (2012) Organometallics 31:8323

27. Paitandi RP, Gupta RK, Singh RS, Sharma G, Koch B, Pandey (2014) Eur J Med Chem 84:17

28. Jaividhya P, Dhivya R, Akbarsha MA, Palaniandavar M (2012) J Inorg Biochem 114:94

29. Rajarajeswari C, Loganathan R, Palaniandavar M, Suresh E, Riyasdeen A, Akbarshae MA (2013) Dalton Trans 42:8347

30. Almes FJM, Porschke D (1993) Biochemistry 32:4246

31. Baron ESG, DeMeio RH, Klemperer F (1936) J Biol Chem 112:625

32. Liu YJ, Liang JH, Li ZZ, Yao JH, Huang HL (2011) J Organomet Chem 696:2728

33. Rajendiran V, Karthik R, Palaniandavar M, Evans HS, Periasamay VS, Akbarsha MA, Srinag BS, Krishnamurthy H (2007) Inorg Chem 46:8208
34. Yu Q, Liu Y, Zhang J, Yang F, Sun D, Liu D, Zhou Y, Liu J (2013) Metallomics 5:222

35. Lackowicz JR, Weber G (1973) Biochem J 12:4161

36. Chyn JP, Urbach FL (1991) Inorg Chim Acta 189:157

37. Vogel AI (1989) Text book of practical organic chemistry. Longman, London

38. Ogiwara Y, Miyake M, Kochi T, Kakiuchi F (2017) Organometallics 36:159

39. Vijayan P, Viswanathamurthi P, Silambarasan V, Velmurugan D, Velmurugan K, Nandhakumar R, Butcher RJ, Silambarasan T, Dhandapani R (2014) J Organomet Chem 768:163

40. SMART \& SAINT (1998) Software reference manuals, version 5.0. Bruker AXS Inc, Madison

41. Sheldrick GM (1997) SHELXL97. Program for Crystal Structure Refinement. University of Gottingen, Gottingen 